\title{
Kesan Psikostres terhadap Kerosakan DNA dan Ketaknormalan Titisan Sitoplasma Sperma Manusia
}

(Effect of Psychostress on DNA Damage and Cytoplasm Droplet Abnormality in Human Sperm)

\author{
NORHAMIZAN HASHIM, KHAIRUL OSMAN*, Siti FATIMAH IBRAHIM, ROSLIAH HARUN \\ \& RAFEAH PAKRI MOHAMED
}

\begin{abstract}
ABSTRAK
Ketidaksuburan idiopati dalam kalangan lelaki telah dikaitkan dengan kesan psikostres. Walaupun begitu, hubungan langsung antara psikostres dan ketaknormalan kualiti semen masih samar. Maka, kajian ini dijalankan untuk menentukan kesan psikostres terhadap kualiti semen terutama kesan berdasarkan titisan sitoplasma dan kerosakan DNA sperma. Dalam kajian ini, responden lelaki berumur antara 25-45 tahun dipilih secara rawak dalam kalangan pesakit yang mendapatkan rawatan di Pusat Kesuburan Lembaga Penduduk dan Pembangunan Keluarga Negara (LPPKN). Seramai 331 responden akhirnya telah dipilih daripada 628 responden selepas mengambil kira faktor penolakan. Setiap responden perlu menjawab borang keizinan dan soal selidik GHQ-12 bagi penentuan tahap stres sebelum pengambilan sampel semen mengikut piawaian WHO (2010). Tahap stres diukur berdasarkan keadaan semasa responden dalam tempoh 3-4 minggu sebelum kajian. Analisis semen, pewarnaan papanicolau dan asai komet neutral digunakan untuk penentuan kualiti semen dan kerosakan DNA sperma. Keputusan menunjukkan tidak terdapat hubungan yang signifikan antara psikostres dan ketaknormalan titisan sitoplasma $(U=895.50, \mathrm{p}=0.08)$. Namun begitu, psikostres memberi kesan kepada peratus morfologi normal $(U=6317.50, \mathrm{p}<0.05)$ dan kerosakan DNA sperma $(U=1047.00, \mathrm{p}<0.01)$. Kesimpulannya, psikostres kronik boleh menjejaskan kualiti semen dan kerosakan DNA sperma serta mempengaruhi kesuburan.
\end{abstract}

Kata kunci: Kerosakan DNA sperma; psikostres; sperma manusia; titisan sitoplasma sperma

ABSTRACT

Idiopathic infertility has been correlated with psychostress in men. Nevertheless, direct relationship of low semen quality to psychostress still remains unclear. Hence, this study was conducted to evaluate the effect of psychostress on semen quality especially on the sperms DNA and cytoplasm droplet abnormality. In this study, respondents within 25-45 years old men were selected randomly among patients of LPPKN. Out of 628, only 331 respondents were selected after reviewing research protocol exclusion criteria. Each respondent was required to fill up a consent form and a GHQ-12 form. The latter was used to measure respondent's stress levels. Stress level was based on respondent's condition 3-4 weeks prior to this study. Semen sample was collected based on WHO (2010) standard semen sample collection protocol. Semen analysis, papanicoulau stain and neutral comet assay were used to measure the semen quality, percentage of sperm cytoplasm droplet abnormality and sperm DNA damage, respectively. The results showed that there was no significant association between psychostress and sperm cytoplasm droplet abnormality $(U=895.50$, $\mathrm{p}=0.08)$. Nevertheless, the percentage of normal morphology $(U=6317.50, \mathrm{p}<0.05)$ and DNA damage $(U=1047.00$, $\mathrm{p}<0.01)$ were affected by psychostress. As a conclusion, chronic psychostress may affect the semen quality and induced sperm DNA damage and influences the fertility eventually.

Keywords: Human sperm; psycostress; sperm cytoplasm droplet; sperm DNA damage

\section{PENGENALAN}

Stres kronik dikatakan menyumbang kepada ketidaksuburan idiopati (Gollenberg et al. 2010; Sapkota et al. 2012). Stres atau tekanan merupakan suatu perasaan yang kurang selesa, kegelisahan, kekhuatiran, kemurungan, bersungut, marah, atau pun suatu perasaan tertekan yang tidak jelas kewujudannya (Beehr 2014). Semua perasaan yang tidak menyenangkan itu jika berlaku secara kronik boleh mengganggu fungsi tubuh (Chrousos et al. 2013). Stres yang berpanjangan boleh menyebabkan perubahan kepada keseimbangan hormon testosteron dalam badan (Levi 2013) yang mengganggu pembentukan sperma (Bhongade et al. 2015).

Kajian terdahulu menyatakan stres meninggalkan implikasi negatif dalam pelbagai parameter yang berkait rapat dengan kualiti semen termasuk kepekatan sperma, motiliti dan morfologi (Bhongade et al. 2015). Kajian kesan stres terhadap organ pembiakan manusia dan kualiti semen telah mendapat perhatian meluas sejak dahulu lagi (Barazani et al. 2014). 
Morfologi sperma merupakan salah satu parameter yang penting dalam menentukan kualiti sperma. Ia digunakan untuk membolehkan persenyawaan berlaku (Agarwal et al. 2014). Morfologi sperma matang yang normal dinilai daripada tiga bahagian utama iaitu kepala, badan (leher) dan ekor (WHO 2010). Kepala sperma mengandungi nukleus yang dipenuhi dengan asid deoksiribonukleik (DNA). DNA merupakan molekul penting dalam pembentukan dan kefungsian sesuatu organisma hidup (Tandara et al. 2014). DNA sperma yang rosak akan menggagalkan proses perkembangan gamet walaupun persenyawaan telah berlaku (Lewis et al. 2013). Benchaib et al. (2007), menyatakan bahawa individu subur memiliki serpihan DNA yang rendah berbanding individu yang tidak subur. Bahagian leher sperma mengandungi mitokondria yang berfungsi membekalkan tenaga kepada ekor untuk membolehkan sperma bergerak. Pembentukan leher sperma yang tidak normal (Cooper et al. 2004) akan mengganggu pergerakan pantas sperma dan menyukarkan proses persenyawaan.

Justeru, kajian ini memfokuskan kepada ketaknormalan pada bahagian leher sperma iaitu berkaitan dengan ketaknormalan titisan sitoplasma dan kerosakan DNA akibat daripada stres yang kronik.

\section{BAHAN DAN KAEDAH}

\section{PENGUMPULAN SAMPEL SEMEN}

Di dalam kajian ini, kelulusan jawatankuasa etika bernombor rujukan UKM1.21.3/244/NHH/-2014-089 telah diperoleh. Sampel semen telah diperoleh daripada 628 pesakit lelaki berumur antara 25-45 tahun yang mendapatkan rawatan di Pusat Kesuburan LPPKN. Proses pengambilan sampel adalah mengikut garis panduan WHO (2010). Kesemua responden perlu menjawab borang keizinan dan soal selidik. Instrumen borang GHQ-12 telah digunakan untuk mengukur tahap stres. Tahap stres dinilai berdasarkan keadaan responden bagi tempoh 3-4 minggu sebelum sampel diambil. Daripada 628 sampel, hanya 331 sampel dipilih setelah mengambil kira faktor penolakan seperti azoospermia, aspermia, merokok dan pengambilan minuman beralkohol.

\section{ANALISIS SEMEN}

Konsenterasi sperma, motiliti sperma dan kiraan total sperma diukur mengikut garis panduan WHO (2010) menggunakan alat pengira Makler. Morfologi sperma pula diukur melalui slaid yang telah dilumur kering dengan sampel semen dan diwarnakan dengan pewarnaan Papanicolaou. Mikroskop cahaya dengan pembesaran $\times 10-\times 100$ telah digunakan untuk menilai kualiti semen tersebut. Isi padu semen diukur menggunakan pipet serologi berskala $10 \mathrm{~mL}$.

\section{ASAI KOMET NEUTRAL}

Sebanyak $200 \mu \mathrm{L} \mathrm{1 \%}$ agaros bertakat lebur normal (NMA) dititiskan di atas permukaan slaid berfros sepenuhnya.
Sisip kaca diletakkan sebelum agaros itu membeku untuk menghasilkan lapisan agaros pertama. Slaid itu kemudiannya dibiarkan pada permukaan ais selama 1015 min untuk agaros membeku. Setelah agaros membeku sepenuhnya, sisip kaca ditanggalkan secara berhati-hati tanpa merosakkan agaros tersebut.

Campuran sel-agaros yang bernisbah $10 \mu \mathrm{L}$ semen $+100 \mu \mathrm{L}$ agaros bertakat lebur rendah (LMA) dititiskan di atas permukaan lapisan agaros pertama. Sisip kaca diletakkan sebelum lapisan sel-agaros membeku. Slaid itu kemudiannya dibiarkan dipermukaan ais selama 1015 min untuk agaros tersebut membeku. Setelah lapisan agaros kedua membeku, sisip kaca ditanggalkan secara berhati-hati tanpa merosakkan lapisan agaros tersebut.

Slaid bermikrogel yang telah disediakan dipindahkan ke dalam bekas berpenimbal lisis pertama dan diinkubasi selama 1 jam pada suhu $37^{\circ} \mathrm{C}$. Setelah itu, slaid bermikrogel tadi dipindahkan ke dalam bekas berpenimbal lisis kedua (mengandungi Proteinase-K) dan diinkubasi selama 1 jam pada suhu $37^{\circ} \mathrm{C}$. Inkubasi bagi lisis pertama dan kedua dibiarkan dalam keadaan gelap. Seterusnya, slaid bermikrogel dipindahkan ke dalam 3 bekas berisi air suling dan direndam selama 10-15 min dalam setiap bekas bagi tujuan pembilasan.

Slaid bermikrogel yang telah melalui proses lisis dan dibilas, kemudiannya dipindahkan ke dalam unit elektroforesis yang mengandungi $1000 \mathrm{~mL}$ penimbal elektroforesis. Slaid itu dibiarkan selama 20 min untuk membolehkan DNA mengendur. Seterusnya, elektroforesis dijalankan pada $25 \mathrm{~V} / 0.01 \mathrm{~A}$ selama $20 \mathrm{~min}$. Selesai elektroforesis, slaid bermikrogel tadi segera dipindahkan ke dalam penimbal neutralisasi dan direndam selama 10 min. Rendaman dengan penimbal neutralisasi baru diulangi sebanyak 2 kali untuk membilas detergen. Kemudian, slaid dikeluarkan dan dibiarkan kering pada suhu bilik sebelum diwarnakan dengan etidium bromida (EtBr) $50 \mu \mathrm{g} / \mathrm{mL}$.

Imej komet dilihat dengan menggunakan mikroskop fluoresen terbalik pada pembesaran $\times 40$ dan kemudiannya dirakam dengan menggunakan kamera AxioCam MRm (Carl Zeiss, Germany). Sekurang-kurangnya 100 sel bagi setiap sampel dirakam dan kesemua rakaman imej komet dianalisis dengan menggunakan perisian Comet Assay Software Project (CASP) versi 1.2.2. Parameter komet yang diambil kira adalah momen ekor komet (peratus DNA yang bermigrasi $\times$ panjang ekor komet).

\section{UJIAN STATISTIK}

Perisian SPSS versi 21 telah digunakan bagi tujuan ini. Pembersihan data dilakukan sebelum ujian statistik. Kenormalan taburan diuji menggunakan ujian KolmogorovSmirnov. Data menunjukkan taburan adalah tidak normal $(p<0.05)$, maka ujian Bukan-Parametrik telah digunakan.

\section{HASIL DAN PERBINCANGAN}

Seramai $80.97 \%$ berbangsa Melayu, $8.16 \%$ berbangsa Cina, $9.67 \%$ berbangsa India dan $1.21 \%$ adalah daripada 
lain-lain bangsa seperti dalam Jadual 1 diambil sebagai responden dalam kajian ini. Julat umur bagi keseluruhan responden adalah antara 22-45 tahun dengan purata umur ( \pm SD) $32.22 \pm 4.53$ seperti dalam Jadual 1

Data yang diperoleh juga menunjukkan sebanyak $61.33 \%$ responden dikategorikan sebagai normal semen, selebihnya dikategorikan sebagai ketaknormalan semen dengan kepelbagaian ciri seperti oligozoospermia, asthenozoospermia, teratozoospermia, oligoasthenozoospermia, oligoteratozoospermia, asthenoteratozoospermia, oligoasthenoteratozoospermia dan hypospermia seperti dalam Jadual 1.

Selain daripada itu, pecahan bilangan responden hasil daripada ujian GHQ-12, mendapati sebanyak 16.92\% daripada keseluruhan responden mencirikan keadaan psikostres dan selebihnya tidak mencirikan keadaan psikostres seperti dalam Jadual 1.

Seterusnya, analisis cecair semen menunjukkan purata \pm SD bagi isi padu semen, konsentrasi sperma, peratus motiliti sperma, kiraan total sperma, peratus normal morfologi sperma dan peratus ketaknormalan titisan sitoplasma sperma, masing-masing adalah $3.13 \pm 1.41$, $28.65 \pm 20.29,57.53 \pm 17.73,85.16 \pm 72.66,10.87 \pm 10.59$ dan $6.08 \pm 6.01$ seperti dalam Jadual 1. Hasil pewarnaan papanicolaou terhadap slaid yang berlumur kering semen diperoleh dengan pembesaran $40 \times$ seperti dalam Rajah 1 . Hasil imej daripada asai komet neutral adalah seperti dalam Rajah 2.

\section{HUBUNGAN PSIKOSTRES DAN KUALITI SEMEN}

Hasil analisis menunjukkan terdapat perbezaan yang signifikan antara responden yang mencirikan psikostres berbanding responden yang mencirikan tidak psikostres terhadap kualiti semen $\left(\chi^{2}=18.65, \mathrm{df}=1, p<0.01\right)$.
Selanjutnya, penyelidik menguji kesan psikostres terhadap kualiti semen secara spesifik. Hasil analisis mendapati bahawa terdapat perbezaan yang signifikan antara responden yang mencirikan psikostres berbanding responden yang mencirikan tidak psikostres terhadap peratus normal morfologi sperma $(\mathrm{U}=6317.50, p<0.05)$.

Namun begitu, hasil analisis menunjukkan tidak terdapat perbezaan yang signifikan antara responden yang mencirikan psikostres berbanding responden yang tidak mencirikan psikostres terhadap isi padu semen ( $\mathrm{U}=7613.00, p=0.89)$, konsenterasi sperma ( $\mathrm{U}=6764.50$, $p=0.15)$, kiraan total sperma $(\mathrm{U}=6875.50, p=0.21)$ motiliti sperma $(\mathrm{U}=7432.00, p=0.68)$ dan ketaknormalan titisan sitoplasma sperma $(\mathrm{U}=895.50, p=0.08)$ seperti dalam Jadual 2.

Secara umumnya, kesuburan lelaki bergantung kepada kualiti semen. Penilaian terhadap kualiti semen boleh diterjemahkan melalui analisis semen dan keutuhan DNA sperma. Isi padu semen, konsenterasi sperma, kiraan total sperma, motiliti dan morfologi adalah antara parameter yang terkandung di dalam analisis semen. Ketaknormalan pada salah satu atau gabungan daripada parameter tersebut boleh menurunkan kualiti semen dan merencat kesuburan lelaki.

Titisan sitoplasma sperma adalah struktur normal pada kebanyakan spesies termasuk manusia. Struktur ini dicirikan dengan pembengkakan sitoplasma pada bahagian leher sperma. Semasa spermatogenesis lengkap, ia akan disingkirkan secara fagositosis oleh sel Sertoli (Cooper 2011). Namun, kewujudannya masih boleh berlaku dan hanya sedikit yang kekal semasa spermiasi. Walau bagaimanapun, kewujudan struktur ini masih dikatakan normal apabila pembesaran saiznya tidak melebihi dua per tiga daripada saiz kepala. Di dalam kajian ini, penyelidik mendapati perbezaan antara responden yang

JADUAL 1. Demografi responden

\begin{tabular}{llcc}
\hline \multicolumn{1}{c}{ Kategori } & \multicolumn{1}{c}{ Pecahan } & Bilangan Responden & Min \pm SD \\
\hline Bangsa & Melayu & 268 & \\
& Cina & 27 & \\
& India & 32 & \\
& Lain-lain & 4 & $32.22 \pm 4.53$ \\
Umur & $\leq 35$ & 251 & \\
Kualiti semen & $>35$ & 80 & \\
& Normozoospermia & 203 & $10.66 \pm 4.57$ \\
Psikostres & Bukan Normozoospermia & 128 & \\
& Ya & 56 & $3.13 \pm 1.41$ \\
Parameter semen & Tidak & 275 & $28.65 \pm 20.29$ \\
& Isipadu semen & 331 & $85.16 \pm 72.66$ \\
& Konsenterasi & 331 & $57.53 \pm 17.73$ \\
& Kiraan total & 331 & $10.87 \pm 10.59$ \\
& Motiliti & 331 & $6.08 \pm 6.01$ \\
\hline
\end{tabular}



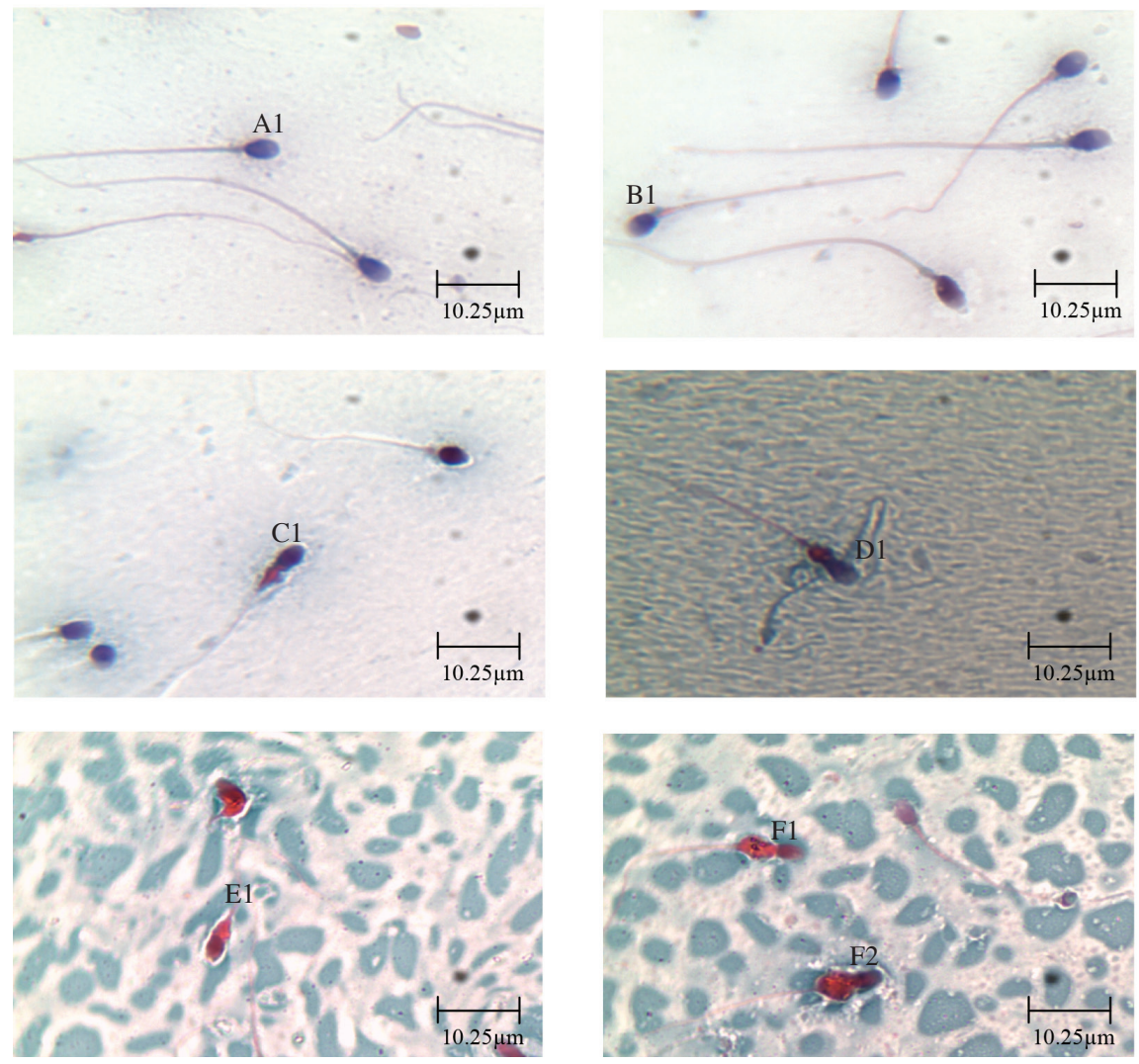

RAJAH 1. Imej sperma yang diwarnakan dengan pewarnaan papanicolaou di bawah pembesaran $\times 60$. Imej A1 menunjukkan sperma yang normal. Imej B1 menunjukkan kecacatan sperma dengan leher bengkok. Imej C1 dan D1 menunjukkan titisan sitoplasma bersaiz 1/3 daripada saiz kepala sperma. Imej E1 menunjukkan titisan sitoplasma bersaiz sama besar dengan kepala sperma. Imej F1 dan F2 menunjukkan titisan sitoplasma bersaiz lebih besar daripada kepala sperma

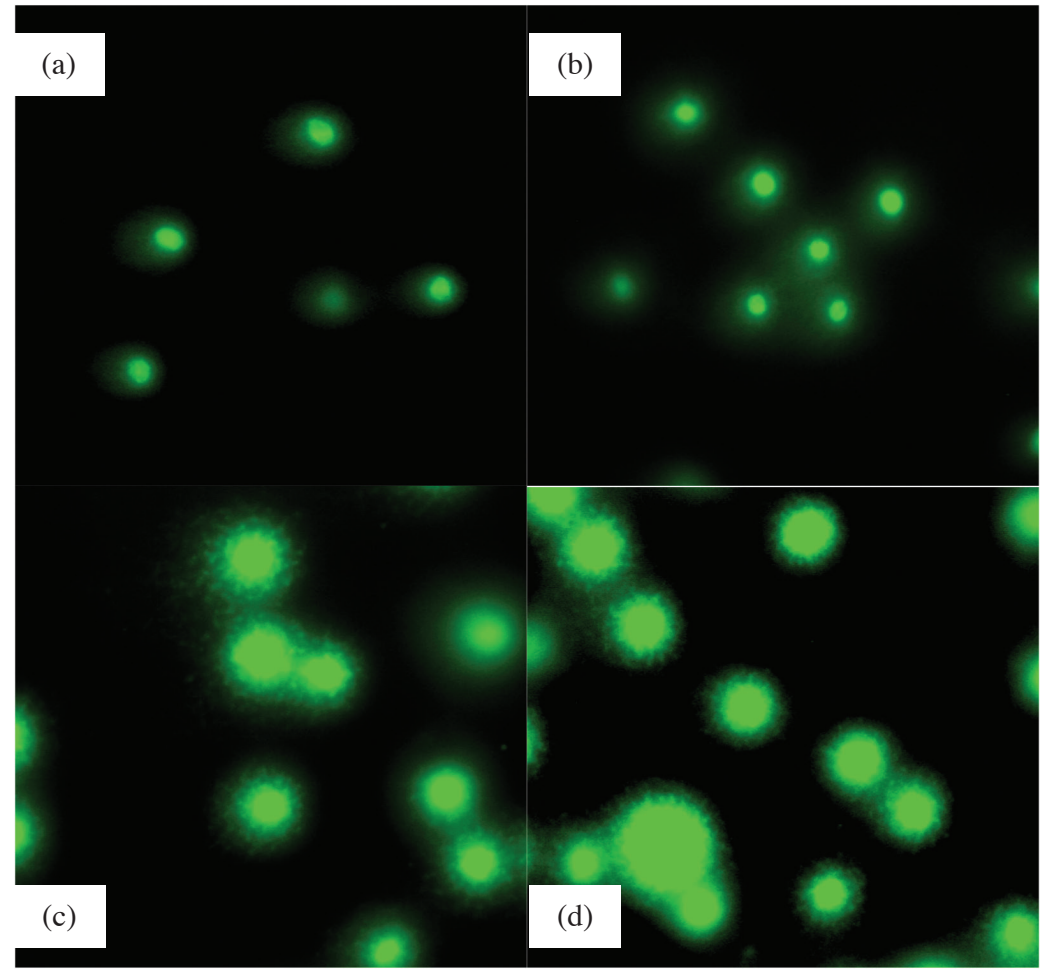

RAJAH 2. Imej sel sperma menunjukkan terdapat fragmentasi berdasarkan komet yang terbentuk. Imej (a) dan (b) berskala $30 \mu \mathrm{m}$ manakala imej (c) dan (d) berskala $15 \mu \mathrm{m}$ 
JADUAL 2. Kesan psikostres terhadap kualiti semen

\begin{tabular}{lcc}
\hline Parameter & Bilangan responden & Min \pm SD \\
\hline Isi padu semen $(\mathrm{mL})$ & 331 & $3.13 \pm 1.41$ \\
Konsenterasi sperma $\left(\times 10^{6} / \mathrm{mL}\right)$ & 331 & $28.65 \pm 20.94$ \\
Kiraan total sperma $\left(\times 10^{6}\right)$ & 331 & $85.16 \pm 72.66$ \\
Motiliti sperma $(\%)$ & 331 & $57.53 \pm 17.73$ \\
Morfologi sperma $(\%)$ & 331 & $10.87 \pm 10.59^{\mathrm{b}}$ \\
Ketaknormalan titisan sitoplasma sperma $(\%)$ & 129 & $6.08 \pm 6.01$ \\
Skor psikostres & 331 & $10.66 \pm 4.57^{\mathrm{a}}$ \\
\hline
\end{tabular}

${ }^{\mathrm{b}}$ menunjukkan perbezaan yang signifikan $(p<0.05)$ berbanding a

stres berbanding responden yang tidak stres terhadap ketaknormalan titisan sitoplasma sperma adalah tidak signifikan pada aras $p<0.05(p=0.08)$. Situasi ini menjelaskan bahawa psikostres tidak mengaruhkan kewujudan ketaknormalan titisan sitoplasma sperma. Oleh yang demikian, keputusan ini menolak hipotesis kajian bahawa psikostres mempengaruhi ketaknormalan titisan sitoplasma sperma.

Di dalam kajian ini juga, didapati terdapat perbezaan yang signifikan diantara responden yang stres berbanding responden yang tidak stres terhadap kualiti semen $(p<0.01)$. Apabila dilihat secara spesifik, kesan stres ternyata mengaruh perubahan bilangan morfologi normal sperma $(p<0.05)$.

Secara asasnya, morfologi normal sperma dicirikan oleh tiga bahagian utama iaitu bahagian kepala, leher dan ekor. Sebarang kecacatan terhadap salah satu bahagian tersebut akan menyebabkan sperma dikira sebagai tidak normal. Ketidaknormalan morfologi sperma ini boleh dikaitkan dengan stres (Bhongade et al. 2015).

Ini adalah kerana apabila tubuh badan berkeadaan stres, kestabilan aras hormon pembiakan boleh terganggu. Situasi stres mengakibat peningkatan aras kortisol dan boleh mencetuskan pengaktifan paksi hipotalamuspituitari-adrenal (HPA). Cetusan ini merangsang perencatan aktiviti hormon pembebas gonadotropin (GnRH) dan mengganggu aras hormon mengluten (LH) dan hormon perangsang folikel (FSH) yang merupakan hormon pembiakan. Perubahan terhadap kedua-dua aras hormon ini akan merangsang perencatan penghasilan testosteron.

Gangguan terhadap aras hormon testosteron akan merangsang perencatan spermatogenesis normal. Spermatogenesis normal memerlukan hormon testosteron pada kadar normal dan seimbang. Ketidakseimbangan aras hormon testosteron boleh menyebabkan perkembangan spermatosit terhenti, perencatan pematangan sperma dan kegagalan menghasilkan spermatozoa (O'Donnell \& McLachlan 2012).

O’Donnell dan McLachlan (2012) mendapati aras hormon testosteron pada testis (340-2000 $\mathrm{nM}$ ) adalah 25-125 kali ganda berbanding pada serum (8.7-35 nM). Menurut beliau lagi, aras FSH dan testosteron pada kepekatan lebih tinggi di serum akan menyebabkan kadar spermatogenesis berlaku lebih pantas, tetapi akan menghasilkan morfologi spermatozoa yang tidak normal. Keputusan ini menunjukkan ketidakseimbangan aras FSH dan testosteron boleh mengganggu pembentukan morfologi normal spermatozoa. Oleh itu, kemerosotan morfologi normal sperma boleh terjadi akibat ketidakseimbangan hormon pembiakan yang terkesan dengan aruhan stres yang akhirnya menyebabkan ketidaksuburan.

Di samping itu, di dalam kajian ini juga, kami mendapati kesan stres terhadap isi padu semen, konsenterasi sperma, kiraan sperma total dan motiliti adalah tidak signifikan pada aras $p<0.05$. Masing-masing bernilai $p=0.89, p=0.15$, $p=0.21$ dan $p=0.68$.

WHO (2010) menetapkan isi padu semen yang normal adalah sekurang-kurangnya $2 \mathrm{~mL}$ setiap ejakulasi. Secara asasnya, jumlah isi padu semen bagi setiap individu lelaki adalah berbeza. Ia berbeza disebabkan kebergantungan kepada kenormalan fungsi kelenjar seks aksesori seperti vesikel semen dan prostat, keupayaan ejakulasi dan kenormalan duktus pembiakan. Dua per tiga daripada isi padu semen adalah merupakan rembesan daripada kelenjar seks aksesori. Ketidaknormalan fungsi kelenjar seks aksesori, kelemahan ejakulasi dan halangan duktus pembiakan boleh mengakibat jumlah isi padu semen di bawah had normal. Oleh yang demikian, keputusan ini menunjukkan fungsi kelenjar seks aksesori dan keupayaan ejakulasi tidak diaruh oleh kesan stres.

Kiraan sperma total adalah hasil konsenterasi sperma didarab dengan isi padu semen. Ini bermakna kiraan sperma total adalah bergantung kepada konsenterasi sperma dan jumlah isi padu semen. Individu oligozoospermia dicirikan dengan nilai konsenterasi sperma di bawah had normal. WHO (2010) menetapkan nilai had normal konsenterasi sperma adalah 20 juta/mL atau lebih. Keputusan kajian ini menunjukkan stres tidak mengaruh pengurangan konsenterasi sperma.

Menurut Garolla et al. (2014), bilangan konsenterasi sperma mempunyai hubungan dengan jumlah sel spermatid bulat pada testis. Kemerosotan sel spermatid akan mengakibatkan konsenterasi sperma menjadi rendah dalam ejakulasi. Ini menunjukkan, stres tidak mengaruh kemerosotan sel spermatid walaupun terdapat potensi berlakunya ketidakseimbangan hormon FSH dan testosteron semasa stres. 
Motiliti sperma merupakan salah satu ciri yang penting untuk membolehkan sperma mensenyawakan osit secara semula jadi. Tanpa ekor atau kecacatan di bahagian ekor, sperma tidak dapat bergerak secara pantas. Epididimis merupakan tempat persinggahan terakhir sperma sebelum dilepaskan semasa ejakulasi. Di epididimis, sperma mengalami proses pematangan sepenuhnya termasuk menjadi motil. Sperma dilepaskan dari organ pembiakan secara ejakulasi bersama-sama dengan rembesan kelenjar seks aksesori.

Menurut Du Plessis et al. (2013), rembesan kelenjar seks aksesori mengandungi fruktosa sebagai sumber tenaga yang berperanan penting di dalam motiliti sperma. Wang et al. (2015) menyatakan, rembesan vesikel semen mengandungi semenogelins iaitu protein gel yang boleh merencat pergerakan sperma. Beliau juga melaporkan rembesan kelenjar seks aksesori mengandungi antigen spesifik prostat (PSA) yang membantu dalam kemotilan sperma melalui degradasi semenogelins.

Mitokondria yang terdapat dibahagian ekor tengah sperma turut memainkan peranan dalam kemotilan sperma dengan menjana tenaga adenosina trifosfat (ATP). Menurut Piomboni et al. (2012), ketidakfungsian mitokondria di bahagian ekor boleh merencat motiliti sperma. Keputusan kajian ini menunjukkan stres tidak mengaruh perencatan fungsi kelenjar seks aksesori dan fungsi mitokondria sperma serta epididimis yang berpotensi merencatkan motiliti sperma.

\section{HUBUNGAN KESAN PSIKOSTRES DAN KUALITI SEMEN} TERHADAP KEROSAKAN DNA SPERMA

Daripada sejumlah 628 responden yang terlibat, hanya 132 responden yang telah diambil kira dalam menentukan perhubungan antara psikostres dan kualiti semen terhadap kerosakan DNA sperma. Jumlah ini diperoleh setelah menyisihkan responden yang merokok dan mengambil minuman beralkohol serta sampel yang rosak.

Keputusan analisis menunjukkan terdapat perbezaan yang signifikan antara responden yang mencirikan psikostres $(n=29)$ berbanding responden yang tidak mencirikan psikostres $(n=103)$ terhadap kerosakan DNA sperma $(\mathrm{U}=1047.00, p<0.01)$. Namun begitu, wujud perbezaan yang tidak signifikan antara kualiti semen yang normal (Normozoospermia) berbanding kualiti semen tidak normal (oligozoospermia, teratozoospermia dan astenozoospermia) terhadap kerosakan DNA sperma $(\mathrm{U}=2098.00, p=0.76)$.
Dalam kajian ini, hasil analisis menunjukkan terdapat perbezaan yang signifikan antara responden yang mencirikan psikostres berbanding responden yang tidak mencirikan psikostres terhadap kerosakan DNA sperma. Keadaaan ini mencadangkan bahawa individu yang menghadapi psikostres akan berhadapan dengan kerosakan DNA sperma yang lebih teruk.

Seperti yang telah dibincangkan, respons stres akan merangsang peningkatan hormon glukokortikoid dan mencetuskan pengaktifan HPA. Cetusan ini mempunyai hubungan dengan alostosis. Walau bagaimanapun, kegagalan alostosis mengaruh pengumpulan hormon glukokortikoid secara berlebihan dan lama-kelamaan akan mewujudkan spesies oksigen reaktif (ROS) (Constantini et al. 2011). Pada tahap minimal, Ros adalah baik untuk sperma, namun apabila Ros wujud secara berlebihan ia akan memberi kesan stres oksidatif dan keadaan ini akan mengancam kenormalan sperma dan seterusnya mencederakan struktur DNA (Chen et al. 2012). Secara teori, ROS berlebihan akan menyerang membran plasma sperma yang kaya dengan asid lemak politaktepu (PUFA) dan membentuk pemperoksidaan lipid (Aitken et al. 2012). Pemperoksidaan lipid seterusnya bertukar menjadi radikal peroksil di dalam tindak balas berantai radikal. Radikal peroksil yang sangat reaktif seterusnya menyebabkan kerosakan peroksidatif terhadap lipid, protein dan DNA (Lobo et al. 2010).

Namun begitu, secara semula jadi DNA sperma terlindung daripada kesan tekanan oksidatif melalui strukturnya yang mampat dan kandungan antioksidan yang terdapat di dalam cecair plasma semen. Struktur DNA sperma yang mampat terhasil daripada ikatan disulfida antara DNA dan protamina (Aoki et al. 2007). Alvarez dan Gosalvez (2012) menyatakan aktiviti tiol oksidase merangsang rangkaian-silang protamina bagi membentuk DNA yang mampat secara berperingkat. Bagi membolehkan enzim ini berfungsi, ia memerlukan penerima elektron dalam bentuk asid lemak hidroperoksida atau fosfolipid hidroperoksida. Ikatan disulfida DNA-protamina menghasilkan sifat gegelung luar biasa (supercoil) yang utuh dan menjadikannya berisi padu rendah berbanding sel somatik. DNA sperma 6 kali lebih mampat dan berisi padu 40 kali kurang daripada DNA sel somatik (Miller et al. 2010). Gegelung luar biasa ini dibungkus di dalam kromatin untuk meminimumkan kecederaan dan kerosakan oleh tekanan oksidatif supaya maklumat genetik yang dibawa oleh sperma boleh dipindahkan dengan sempurna (Aitken et al. 2012).

JADUAL 3. Hubungan psikostres dan kualiti semen terhadap kerosakan DNA sperma

\begin{tabular}{lcc}
\hline Parameter & Bilangan responden & Min \pm SD \\
\hline Momen ekor DNA sel sperma & 132 & $1.12 \pm 0.76^{\mathrm{a}}$ \\
Psikostres skor & 132 & $1.23 \pm 0.42^{\mathrm{b}}$ \\
Kualiti semen & 132 & $1.46 \pm 0.50$ \\
\hline
\end{tabular}

${ }^{\mathrm{b}}$ Menunjukkan perbezaan yang signifikan $(p<0.05)$ berbanding a 
Menurut Puglisi et al. (2014), fosfolipid glutation peroksidase berperanan sebagai antioksidan dalam membentuk DNA yang mampat melalui kesan oksidasi tiol dengan kehadiran Ros pada tahap optimum. Walau bagaimanapun, pada tahap ROS yang berlebihan, wujud tekanan oksidatif yang akan mengakibatkan kemerosotan glutation peroksidase dan akhirnya berpotensi merosakkan DNA. Ini menunjukkan keupayaan mekanisme perlindungan antioksidan seperti glutation peroksidase, superoksida dismutase dan katalase mempunyai limitasi (Kashou et al. 2013). Kemerosotan mekanisme perlindungan ini berakhir dengan kerosakan DNA serta kematian sel. Oleh yang demikian, kajian ini mencadangkan bahawa psikostres boleh memberi kesan terhadap kerosakan DNA sperma melalui tekanan oksidatif.

\section{KESIMPULAN}

Di dalam kajian ini, psikostres kronik didapati mengaruh kemerosotan peratus morfologi dan kerosakan DNA sperma. Keadaan ini menunjukkan psikostres berpotensi menyebabkan kemerosotan kualiti semen dan ketidaksuburan. Morfologi normal dan keutuhan DNA sperma merupakan bioindikator yang kuat untuk meramalkan keberjayaan persenyawaan. Kegagalan kumpulan ketaksuburan idiopati untuk memperoleh zuriat di awal perkahwinan boleh dijelaskan dengan kemerosotan peratus normal morfologi dan kerosakan DNA.

Kesan psikostres terhadap ketaknormalan titisan sitoplasma sperma adalah minimal dan tidak dapat dikaitkan dengan kumpulan ketaksuburan idiopati. Namun begitu, pemahaman terhadap ketaknormalan titisan sitoplasma sperma perlu diperhalusi dan dikembangkan. Ini mungkin boleh dilihat daripada sudut fungsi dan peranan sebenar ketaknormalan titisan sitoplasma terhadap sperma. Mungkin juga kehadiran ketaknormalan struktur ini memberi kebaikan kepada sperma. Bagi tujuan itu, pemilihan responden dengan faktor penolakan tertentu perlu diperincikan.

\section{PENGHARGAAN}

Kajian ini telah ditaja oleh Kementerian Pengajian Tinggi melalui peruntukan FRGS/2/2013/SKK10/UKM/02/03, Universiti Kebangsaan Malaysia, Lembaga Penduduk dan Pembangunan Keluarga Negara, Malaysia dan Jabatan Perkhidmatan Awam, Malaysia.

\section{RUJUKAN}

Agarwal, A., Tvrda, E. \& Sharma, R. 2014. Relationship amongst teratozoospermia, seminal oxidative stress and male infertility. Reprod. Biol. Endocrinol. 12(1): 45.

Aitken, R.J., Jones, K.T. \& Robertson, S.A. 2012. Reactive oxigen species and function-in sickness and in health. Journal of Andrology 33(6): 1096-1106.

Alvarez, J.G. \& Gosalvez, J. 2012. Role of Protamine Disulphide Cross-Linking in Counteracting Oxidative Damage to DNA. New York: Humana Press. pp. 221-235.
Aoki, V.W., Emery, B.R.,Liu, L. \& Carrell, D.T. 2007. Protamine levels vary between individual sperm cells of infertile human males and correlate with viability and DNA intergrity. Journal of Andrology 27(6): 890-898.

Barazani, Y., Katz, B.F., Nagler, H.M. \& Stember, D.S. 2014. Lifestyle, environment, and male reproductive health. Urologic Clinics of North America 41(1): 55-66.

Beehr, T.A. 2014. Psychological Stress in the Workplace (Psychology Revivals). Oxford: Routledge.

Benchaib, M., Lornage, J., Mazoyer, C., Lejeune, H., Salle, B.\& Guerin, J.F. 2007. Sperm deoxyribonucleic acid fregmentation as a prognostic indicator of assisted reproductive technology outcome. Fertility and Sterility 87(1): 93-100.

Bhongade, M.B., Prasad, S., Jiloha, R.C., Ray, P.C., Mohapatra, S. \& Koner, B.C. 2015. Effects of psychological stress on fertility hormones and seminal quality in male partner of infertility couples. Andrologia 47(3): 336-342.

Chen, H., Zhao, H.X., Huang, X.F., Chen, G.W., Yang, Z.X., Sun, W.J., Tao, M.H., Yuan, Y., Wu, J.Q., Sun, F., Dai, Q. \& Shi, H.J. 2012. Does high load of oxidants in human semen contribute to male factor infertility? Antioxidants \& Redox Signaling 16(8): 754-759.

Chrousos, G.P., Loriaux, D.L. \& Gold, P.W. 2013. Mechanisms of Physical and Emotional Stress (Vol. 245). New York: Springer Science \& Business Media.

Constantini, D., Marasco, N. \& Moller, A.P. 2011. A meta analysis of glucocorticoids as modulator of oxidative stress in vertebrate. Comp. Physiol. B. 181(4): 447-456.

Cooper, T.G. 2011. The epididymis, cytoplasmic droplet and male fertility. Asian Journal of Andrology 13(1): 130-138.

Cooper, T.G., Yeung, C.H., Fetic, S., Sobhani, A. \& Nieschlag, E. 2004. Cytoplasmic droplet are normal structures of human sperm but are not preserved by routine procedure for assessing sperm morphology. Human Reproduction 19(10): 2283-2288.

Du Plessis, S.S., Gokul. \& Agarwal, A. 2013. Semen hyperviscosity: Causes, consequences and cures. Front Biosci.(Elite Ed) 5(1): 224-231.

Garolla, A., Selice, R., Engl, B., Bertoldo, A., Menegazzo, M., Finos, L., Lenzi, A. \& Foresta, C. 2014. Spermatid counts as a predictor of response to fish therapy. Reproductive Biomedicine Online 29(1): 102-112.

Gollenberg, A.L., Liu, F., Brazil, C., Drobnis, E.Z., Guzick, D., Overstreet, J.W., Redmon, J.B., Spark, A., Wang, C. \& Swan, S.H. 2010. Semen quality in fertile men in relation to psychosocial stress. Fertility and Sterility 93(4): 1104-1111.

Kashou, A.H., Sharma, R. \& Agarwal, A. 2013. Assessment of oxidative stress in sperm and semen. Spermatogenesis: Methods and Protocol, Methods in Molecular Biology 927: 351-361.

Levi, L. (red). 1973. Stress and Distress in Response to Psychosocial Stimuli: Laboratory and Real-Life Studies on Sympatho-Adrenomedullary and Related Reactions. Oxford: Pergamon Press.

Lewis, S.E., Aitken, R.J., Conner, S.J., De Iuliis, G., Evenson, D.P., Henkel, R., Giwercman, A. \& Gharagozloo, P. 2013. The impact of sperm DNA damage in assisted conception and beyond: Recent advances in diagnosis and treatment. Reproductive Biomedicine Online 27(4): 325-337.

Lobo, V., Patil, A., Phatak, A. \& Chandra, N. 2010. Free radicals, antioxidants and functional food: Impact on human health. Pharmaco.Rev. 4(8): 118-126.

Miller, D., Brinkworth, M. \& Iles. 2010. Paternal DNA packaging in spermatozoa: More than sum of its parts? DNA, histone, protamines and epigenetics. Reproduction 139(2): 287-301. 
O’Donnell, L. \& McLachlan, R.I. 2012. The role of testosterone in spermatogenesis. In Testosterone: Action, Deficiency, Substitution. 4th ed, edited by Nieschlag, E. \& Behre, H.M. Cambridge: Cambridge University Press. pp. 123-153.

Piomboni, P., Focarelli, R., Stendardi, A., Ferramosca,A. \& Zara, V. 2012. The role of mitochondria in energy production for human sperm motility. International Journal of Andrology 35(2): 109-124.

Puglisi, R., Maccari, I., Pipolo, S., Mangia, F. \& Boitani, C. 2014. The nuclear form of glutathione peroxidase 4 colocalizes and directly interacts with protamines in the nuclear matrix during mouse sperm chromatin assembly. Spermatogenesis 4(1): e28460.

Sapkota, N.K., Shah, D.K. \& Islam, M.N. 2012. Stress and infertility - An overview. International Journal of Pharmaceutical \& Biological Archives 3(5): 1017-1024.

Tandara, M., Bajić, A., Tandara, L., Bilić-Zulle, L., Šunj, M., Kozina, V., Goluža, T. \& Jukić, M. 2014. Sperm DNA integrity testing: Big halo is a good predictor of embryo quality and pregnancy after conventional IVF. Andrology 2(5): 678-686.

Wang, Z., Liu, B., Su, S. \& Tang, M. 2015. Semen liquefaction molecular pathways. Translational Andrology and Urology 4(1): AB073.

World Health Organisation. 2010. WHO Laboratory Manual for the Examination and Processing of Human Semen.
Norhamizan Hashim \& Khairul Osman*

Program Sains Forensik

Fakulti Sains Kesihatan

Universiti Kebangsaan Malaysia

50300 Jalan Raja Muda, Kuala Lumpur

Malaysia

Siti Fatimah Ibrahim \& Rafeah Pakri Mohamed

Jabatan Fisiologi, Fakulti Perubatan

Universiti Kebangsaan Malaysia, Jalan Yaacob Latiff

56000 Kuala Lumpur, Wilayah Persekutuan

Malaysia

Rosliah Harun

Bahagian Reproduksi Manusia

Lembaga Penduduk dan Pembangunan Keluarga Negara (LPPKN)

Jalan Raja Laut

50350 Kuala Lumpur, Wilayah Persekutuan

Malaysia

*Pengarang untuk surat-menyurat; email: khairos@ukm.edu.my

Diserahkan: 17 Februari 2016

Diterima: 14 Oktober 2016 